\title{
Profil Kesalahan Mahasiswa dalam Menyelesaikan Soal pada Mata Kuliah Kalkulus Diferensial berdasarkan Gaya Kognitif dan Habits of Mind
}

\author{
Hayatun Nufus ${ }^{1}$, Rezi Ariawan ${ }^{2}$ \\ ${ }^{1}$ Pendidikan Matematika, Universitas Islam Negeri Sultan Syarif Kasim Riau \\ ${ }^{2}$ Pendidikan Matematika, Universitas Islam Riau \\ e-mail: hayatun.nufus@uin-suska.ac.id
}

\begin{abstract}
ABSTRAK. Penelitian ini bertujuan untuk mendeskripsikan profil kesalahan mahasiswa dalam menyelesaikan soal pada mata kuliah kalkulus differensial berdasarkan gaya kognitif dan habits of mind. Metode penelitian yang digunakan adalah penelitian deskriptif kuantitatif dengan subjek penelitian adalah mahasiswa semester 3 jurusan Pendidikan Matematika FTK UIN Suska Riau semester ganjil 2017/2018 yang sedang menempuh mata kuliah kalkulus peubah banyak. Intrumen pengumpul data yang digunakan dalam penelitian ini terdiri dari lembar GEFT untuk mengidentifikasi gaya kognitif, lembar angket habits of mind untuk memperoleh informasi tentang habits of mind mahasiswa, serta lembar tes soal kemampuan berpikir koneksi matematis. Teknik pengumpulan data dalam penelitian ini terdiri dari teknik tes dan teknik nontes. Teknik analisis data dilakukan dengan teknik deskriptif kuantitatif. Berdasarkan hasil penelitian diperoleh informasi bahwa kesalahan yang dilakukan mahasiswa dalam menyelesaikan soal pada mata kuliah differensial terbagi atas tiga jenis kesalahan, yaitu kesalahan fakta, operasi dan prinsip serta kesalahan yang paling banyak dilakukan adalah kesalahan prinsip.
\end{abstract}

Keywords : Profil Kesalahan, Gaya Kognitif, Habits of Mind

\section{PENDAHULUAN}

Kalkulus merupakan sebuah mata kuliah yang hampir ada pada setiap perguruan tinggi terutama pada jurusan matematika dan sains. Kalkulus juga menjadi salah satu mata kuliah keahlian yang wajib diambil dan dituntaskan (lulus) oleh mahasiswa yang mengambil jurusan eksak, salah satunya adalah mahasiswa yang kuliah pada jurusan pendidikan matematika. Pada jurusan pendidikan matematika Fakultas Tarbiyah dan Keguruan UIN Suska Riau, mata kuliah kalkulus merupakan mata kuliah wajib yang dibagi menjadi tiga jenis mata kuliah, yaitu kalkulus diferensial, kalkulus integral dan kalkulus peubah banyak. Kalkulus diferensial diberikan disemester satu, kalkulus integral disemester dua dan kalkulus peubah banyak disemester tiga.

Materi pokok yang ada pada ketiga mata kuliah ini merupakan dasar konsep yang akan digunakan pada mata kuliah-mata kuliah matematika lainnya, baik itu matematika terapan maupun matematika murni. Dari ketiga mata kuliah ini, yang paling mendasar dan mutlak harus dikuasai adalah mata kuliah kalkulus diferensial. Hal ini karena materi yang termuat pada mata kuliah ini digunakan pada mata kuliah kalkulus integral dan peubah banyak. Artinya, sebelum mahasiswa mencoba memahami materi pada mata kuliah kalkulus integral dan kalkulus peubah banyak, maka mereka harus terlebih dahulu memahami (menguasai dengan baik) materi kalkulus diferensial.

Mengingat begitu pentingnya mata kuliah kalkulus diferensial, maka diharapkan mahasiswa memiliki kemampuan yang baik dalam menguasai dan memahami mata kuliah ini. Untuk dapat meningkatkan penguasaan mahasiswa pada mata kuliah kalkulus diferensial, maka salah satu cara 
yang dapat dilakukan oleh dosen sebagai tenaga pengajar adalah melakukan penyelidikan terhadap penguasaan mahasiswa tersebut.

Penyelidikan tersebut salah satunya berupa penyelidikan terhadap kesalahan yang dilakukan mahasiswa dalam menyelesaikan soal-soal kalkulus diferensial. Hasil akhir dari penyelidikan ini dapat memberikan gambaran tentang jenis kesalahan yang dilakukan, sehingga dosen sebagai tenaga pengajar bisa mengambil langkah penyelesaian yang lebih tepat karena fokus dan konsentrasi perbaikan menjadi lebih sempit dan tidak mengambang. Gambaran kesalahan akan lebih terlihat pada jawaban mahasiswa terhadap soal yang bersifat uraian.

Kesalahan yang dilakukan mahasiswa dalam menyelesaikan soal uraian pada mata kuliah kalkulus diferensial dapat dipengaruhi oleh beberapa faktor, salah satu diantaranya adalah gaya kognitif. Menurut Sternberg dan Elena (1997), gaya kognitif merupakan jembatan antara kecerdasan dan kepribadian. Menurut Woolfolk (1993), gaya kognitif adalah suatu cara yang berbeda untuk melihat, mengenal, dan mengorganisasi informasi. Setiap individu memiliki cara tertentu yang disukai dalam memproses dan mengorganisasi informasi sebagai respon terhadap stimulasi lingkungannya. Witkin (1977) menyatakan bahwa gaya kognitif terdiri dari field independent dan field dependent. Seseorang yang memiliki gaya kognitif field independent pada umumnya lebih independent, kompetitif, dan percaya diri, sedangkan seseorang yang tergolong ke dalam gaya kognitif field dependent lebih cenderung bersosialisasi, lebih berempati dan menyatu diri dengan orang lain disekitar mereka. Hal senanda juga dinyatakan oleh O'Brien et al (2001) yang menyatakan bahwa individu field independent sering disebut sebagai analytical thinkers sedangkan individu field dependent sering disebut sebagai global thinkers.

Berdasarkan beberapa pendapat para ahli di atas dapat dinyatakan bahwa gaya kogninif seseorang dapat menunjukkan variasi individu dalam hal perhatian, penerimaan informasi, mengingat, dan berpikir yang muncul atau berbeda diantara kognisi dan kepribadian. Oleh karena itu, peneliti menganggap sangat penting untuk melihat aspek gaya kogntinif dalam hal untuk mengindentifikasi kesalahan mahasiswa dalam menyelesaikan soal pada mata kuliah kalkulus diferensial.

Faktor lain yang dapat mempengaruhi kesalahan mahasiswa dalam menyelesaikan soal uraian mata kuliah kalkulus diferensial adalah aspek habits of mind. Menurut Costa dan Kallick (2008) babits of mind merupakan karakteristik dari apa yang dilakukan oleh orang cerdas ketika dihadapkan dengan permasalahan yang solusinya tidak dapat diketahui dengan mudah. Menurut Marita (2014) habits of mind adalah sekelompok keterampilan, sikap, dan nilai yang memungkinkan orang untuk memunculkan kinerja atau kecerdasan tingkah laku berdasarkan stimulus yang diberikan untuk membimbing mahasiswa menghadapi atau menyelesaikan isu-isu yang ada. Berdasarkan beberapa penjelasan tersebut, maka dapat disimpulkan bahwa habits of mind merupakan aspek yang sangat penting untuk ditelusuri, terutama pada kesalahan yang dilakukan oleh mahasiswa dalam menyelesaikan soal uraian pada mata kuliah kalkulus diferensial.

Harriyani (2014) menyatakan bahwa objek kajian matematika terdiri dari fakta, konsep, operasi dan prinsip. Objek kajian matematika tersebut dapat diamati pada saat seseorang atau individu sedang atau telah melakukan atau menyelesaikan persoalan yang berkaitan dengan matematika. Dalam menyelesaikan persoalan matematika, maka objek kajian matematika tersebut harus digunakan. Apabila dalam penyelesaian persoalan matematika tidak menggunakan objek kajian matematika tersebut, maka dapat dinyatakan bahwa individu tersebut telah melakukan kesalahan atau dalam penyelesaian persoalannya terdapat kekurangan. Sukirman dalam Zainal Abidin (2012) menyatakan bahwa kesalahan merupakan penyimpangan terhadap hal yang benar yang sifatnya sistematis, konsisten, maupun incidental pada daerah tertentu. Kesalahan yang sifatnya konsisten dan sistematis disebabkan oleh kompetensi mahasiswa, sedangkan yang sifatnya insidental bukan merupakan akibat rendahnya tingkat penguasaan materi pelajaran.

Senada dengan pendapat di atas, Lenner dalam Abdurrahman (2003) menyatakan ada beberapa kesalahan yang dilakukan dalam belajar matematika, yaitu: (a) kekurangan pemahaman tentang simbol; (b) mengenai nilai tempat; (c) penggunaan proses yang keliru; (d) kesalahan 
dalam perhitungan; (e) kesalahan dalam penulisan. Kesalahan-kesalahan yang dilakukan dalam belajar matematika, tidak terlepas dari karakteristik matematika itu sendiri. Berdasarkan uraian penjelasan di atas, maka peneliti tertarik untuk melakukan penelitian dengan judul "Profil kesalahan mahasiswa dalam menyelesaikan soal pada mata kuliah kalkulus diferensial berdasarkan gaya kognitif dan habits of mind"

\section{METODE PENELITIAN}

Jenis penelitian yang digunakan dalam penelitian ini adalah deskriptif. Menurut Sukmadinata (2010) penelitian deskriptif adalah suatu bentuk penelitian yang paling dasar, yang ditujukan untuk mendeskripsikan atau menggambarkan fenomena-fenomena yang ada, baik fenomena yang bersifat alamiah maupun rekayasa manusia. Penelitian deskriptif dapat juga ditujukan untuk mengadakan kajian yang bersifat kuantitatif. Penelitian deskriptif tidak memberikan perlakuan atau pengubahan pada variabel-variabel bebeas, tetapi menggambarkan suatu kondisi apa adanya. Artinya peneliti tidak melakukan manipulasi atau memberikan perlakuan tertentu terhadap variabel atau merancang sesuatu yang yang diharapkan terjadi pada variabel, tetapi semua kegiatan, keadaan, kejadian, aspek, komponen atau variabel berjalan sebagaimana adanya. Satu-satunya unsur manipulasi atau perlakuan yang yang diberikan hanyalah penelitian itu sendiri, yang dilakukan melalui observasi, wawancara, pengedaran angket atau studi dokumentasi. Senada dengan pendapat di atas, Suryabrata (2014) menyatakan bahwa penelitian deskritptif merupakan penelitian yang bermaksud untuk membuat pencandraan (deskripsi) mengenai situasi-situasi atau kejadian-kejadian. Artinya adalah penelitian deskriptif itu adalah akumulasi data dasar dalam cara deskriptif semata-mata tidak perlu mencari atau menerangkan sebuah hubungan, menguji hipotesis, membuat ramalan atau membuat makna dan mendapatkan implikasi.

Berdasarkan uraian diatas, maka penelitian ini adalah penelitian deskriptif kuantitatif dengan menggambarkan secara apa adanya apa yang terjadi dilapangan tanpa memberikan perlakuan apapun yang disajikan dalam bentuk angka dan narasi tertulis. Subjek dalam penelitian ini adalah mahasiswa semester 3 Jurusan Pendidikan Matematika FTK UIN Suska Riau semester ganjil tahun ajaran 2017/2018 yang sedang menempuh mata kuliah kalkulus peubah banyak. Pemilihan subjek penelitian ini didasari karena mahasiswa semester 3 yang sedang belajar kalkulus peubah banyak sebelumnya pasti harus lulus mata kuliah kalkulus diferensial dan telah mengikuti perkuliahan pada mata kuliah kalkulus integral, dimana ketiga mata kuliah ini akan senantiasa menggunakan konsep kalkulus diferensial.

Untuk mendapatkan data yang dibutuhkan dalam penelitian ini, maka peneliti menggunakan sejumlah instrumen yang peneliti namakan sebagai instrumen bantu. Intrumen bantu pertama berupa lembar GEFT. Lembar GEFT yang peneliti gunakan merupakan instrumen tes yang telah dikembangkan oleh Witkin (1971) yang digunakan untuk memperoleh informasi tentang gaya kognitif individu yang sudah memenuhi syarat instrumen yang baik, dimana instumen GEFT tersebut memiliki tingkat reliabilitas sebesar 0,84 dengan kategori sangat tinggi (Khodadady dan Tafaghodi dalam Ulya, 2015).

Selanjutnya untuk mendapatkan data berupa informasi tentang habits of mind mahasiswa, maka peneliti menggunakan lembar angket habits of mind yang peneliti namakan sebagai instrumen bantu ke dua. Sedangkan untuk mendapatkan informasi tentang jenis kesalahan yang dilakukan oleh mahasiswa, maka peneliti menggunakan instrumen tes berupa soal uraian berbasis kemampuan koneksi matematis. Instrumen tes berupa soal tersebut peneliti namakan sebagai instrumen bantu ketiga.

Dalam menggunakan ketiga instrumen pengumpul data tersebut, peneliti menggukan beberapa teknik. Teknik pengumpulan data berupa teknik tes digunakan untuk instrumen bantu ketiga dan instrumen bantu pertama, sedangkan instrumen bantu ke dua menggunakan teknik nontes. 
Teknik analisis data yang digunakan untuk menganalisis data yang diperoleh adalah teknik analisis data deskriptif kuantitatif. Semua data yang diperoleh melalui instrumen bantu yang digunakan, akan di analisis menggunakan teknik analisis data deskriptif kuantitatif.

\section{HASIL}

Berdasarkan lembar tes GEFT yang sudah diberikan kepada mahasiswa maka diperoleh informasi bahwa subjek penelitian terbagi ke dalam dua kategori gaya kognitif yaitu field Independent dan field dependent. Jumlah subjek penelitian dengan gaya kognitif field independent lebih sedikit jika dibandingkan dengan subjek gaya kognitif field dependent. Berikut akan disajikan data terkait jumlah subjek penelitian berdasarkan gaya kongitif.

Tabel 1. Rekapitulasi Pengelompokkan Mahasiswa berdasarkan Gaya Kognitif

\begin{tabular}{lcc}
\hline Jenis Gaya Kognitif & Banyak Mahasiswa & Persentase \\
\hline Field Independent & 6 orang & $27,27 \%$ \\
\hline Field Dependent & 16 orang & $72,73 \%$ \\
\hline Jumlah & 22 orang & $100 \%$ \\
\hline Sumber: Data Olahan Peneliti & &
\end{tabular}

Berdasarkan data di atas, dapat dikatakan bahwa sebagian besar mahasiswa yang merupakan subjek dalam penelitian ini merupakan orang-orang yang dikenal sebagai global thinker dan lebih mengandalkan dengan cara menghafal untuk menerima informasi. Selain gaya kognitif, maka peneliti juga sudah memberikan lembar angket habits of mind kepada subjek penelitian. Pada habits of mind, maka ada tiga aspek yang peneliti amati yaitu self regulation, critical thinking dan creative thinking. Berikut akan disajikan persentase aspek dari habits of mind.

Tabel 2. Rekapitulasi Kriteria Habit of Mind Berdasarkan Kategori Habits of Mind

\begin{tabular}{ccccc}
\hline Kategori HoM & Skor Total & $\begin{array}{c}\text { Skor } \\
\text { Maksimal }\end{array}$ & Persentase & Kriteria \\
\hline Self Regulation & 313 & 440 & 71,14 & Baik \\
\hline Critical Thinking & 324 & 440 & 73,64 & Baik \\
\hline Creative Thinking & 160 & 264 & 60,61 & Cukup Baik \\
\hline
\end{tabular}

Sumber: Data Olahan Peneliti

Data yang disajikan pada tabel 2 di atas memberikan informasi bahwa 2 dari 3 kategori habits of mind mahasiswa termasuk ke dalam kriteria baik. Berdasarkan data di atas juga dapat dinyatakan bahwa belum terdapat kriteria dari kategori habits of mind mahasiswa yang termasuk ke dalam kategori sangat baik, cukup dan kurang.

\section{PEMBAHASAN}

Peneliti memperoleh kesimpulan jenis kesalahan yang dilakukan mahasiswa dengan memperhatikan penjelasan hasil penelitian. Kesimpulan tersebut dapat dilihat pada kedua tabel berikut: 
Tabel 3. Kesimpulan kesalahan Gaya Kognitif Field Dependent

\begin{tabular}{|c|c|c|c|c|}
\hline Kategori HoM & Sampel & Soal Nomor & Skor & $\begin{array}{c}\text { Kesalahan yang } \\
\text { dilakukan }\end{array}$ \\
\hline \multirow{3}{*}{ Sangat Baik } & \multirow{3}{*}{ YY } & 1 & 4 & - \\
\hline & & 2 & 4 & - \\
\hline & & 3 & 2 & Prinsip \\
\hline \multirow{3}{*}{ Baik } & \multirow{3}{*}{$\mathrm{SN}$} & 1 & 1 & operasi \\
\hline & & 2 & 4 & - \\
\hline & & 3 & 1 & Prinsip \\
\hline \multirow{3}{*}{ Cukup Baik } & \multirow{3}{*}{ SU } & 1 & 1 & prinsip \\
\hline & & 2 & 4 & - \\
\hline & & 3 & 0 & operasi \\
\hline
\end{tabular}

Sumber: Data Olaban Peneliti

Berdasarkan data di atas, diperoleh informasi bahwa subjek yang termasuk ke dalam kategori HoM Sangat Baik hanya melakukan kesalahan prinsip, sedangkan sunjek yang termasuk ke dalam kategori HoM Baik dan Cukup Baik, sama-sama melakukan kesalahan prinsip dan operasi. Secara keseluruhan subjek yang memiliki gaya kognitif field Dependent tidak melakukan kesalahan fakta untuk semua kategori HoM.

Tabel 2. Kesimpulan kesalahan Gaya Kognitif Field Independent

\begin{tabular}{ccccc}
\hline Kategori HoM & Sampel & Soal Nomor & Skor & $\begin{array}{c}\text { Kesalahan yang } \\
\text { dilakukan }\end{array}$ \\
\hline \multirow{2}{*}{ Sangat Baik } & \multirow{2}{*}{ NA } & 1 & 4 & - \\
\cline { 3 - 5 } & & 2 & 4 & - \\
\cline { 3 - 5 } Baik & \multirow{2}{*}{ BW } & 3 & 2 & Prinsip \\
\cline { 3 - 5 } & & 2 & 2 & Fakta \\
\cline { 3 - 5 } Cukup Baik & \multirow{2}{*}{ SWP } & 3 & 1 & Prinsip \\
\cline { 3 - 5 } & & 2 & 2 & Fakta \\
\cline { 3 - 5 } & & 3 & 4 & Operasi \\
\hline
\end{tabular}

Sumber: Data Olaban Peneliti

Pada kedua tabel di atas, terlihat bahwa mahasiswa paling sering melakukan kesalahan operasi dibandingkan tiga kesalahan lainnya. Ini artinya kesalahan yang paling banyak dilakukan mahasiswa adalah mahasiswa tidak terampil dalam menghubungkan antar konsep atau fakta yang terdapat dalam ilmu matematika, apalagi antara teori matematika dengan kondisi permasalahan yang berupa soal cerita (hubungan matematika dengan bidang lain dan kehidupan sehari-hari).

Selanjutnya, setelah diperhatikan lebih seksama, ternyata tidak ditemui mahasiswa yang melakukan kesalahan konsep. Setelah memperhatikan dengan seksama bunyi soal dan alternatif jawaban yang telah peneliti susun, barulah peneliti menyadari bahwa memang dari ketiga soal yang diberikan, tidak akan memungkinkan mahasiswa melakukan kesalahan konsep. Hal ini karena dari ketiga soal tersebut memang tidak ada yang menuntut secara langsung penguasaan konsep mahasiswa dalam mengklasifikasikan suatu objek apakah termasuk contoh atau bukan contoh dari suatu ide matematika.

Berdasarkan jawaban yang diberikan mahasiswa, terdapat satu keunikan, yaitu jawaban dari mahasiswa yang termasuk dalam kelompok field independent dengan kategori habits of mind pada level sangat baik. Mahasiswa ini (NA) memberikan jawaban dengan cara yang tidak lazim. NA menuliskan cara yang berbeda dalam menjawab, cukup panjang dan lengkap. Setelah diperhatikan dengan seksama uraian langkah yang diberikan cukup logis, namun tidak memberikan jawaban yang tepat karena memang sudah terdapat kesalahan di keputusan awal menjawab. Ini berarti memang sesuai untuk gaya kognitif dengan level habits of mind jenis ini. Hanya NA yang masuk dalam kategori creative thinking level baik. Artinya, memang NA mampu menyajikan penyelesaian dengan cara yang kreatif (baru, unik) dengan langkah-langkah yang analitis (independent). 
Selanjutnya, peneliti juga menemukan bahwa salah seorang mahasiswa (R) yang termasuk dalam kelompok field dependent dengan level babits of mind cukup baik (paling rendah pada penelitian ini), namun memiliki skor tes paling tinggi untuk kelompok field independent saja dan tertinggi kedua untuk seluruh mahasiswa (gabungan field dependent dan field independent). Peneliti berasumsi bahwa $\mathrm{R}$ memang memiliki dasar kemampuan kalkulus diferensial yang baik, karena memang materi kalkulus diferensial sebelumnya pernah diajarkan pada jenjang SMA (materi pokok turunan). Mungkin kategori level habits of mind nya cukup baik, tapi karena materi ini sudah pernah diterima sebelumnya (SMA dan semester 1 pada mata kuliah kalkulus diferensial) sementara $\mathrm{R}$ saat ini adalah mahasiswa semester 3 yang telah mengambil mata kuliah kalkulus integral dan sedang mengambil mata kuliah kalkulus peubah banyak, maka peneliti merasa wajar. Hal ini karena memang $\mathrm{R}$ masuk dalam kelompok field dependent yang gaya kognitif mahasiswanya cenderung menghapal dan $\mathrm{R}$ sendiri telah berulang kali menerima dan menggunakan konsep kalkulus diferensial (perlu diingat sebelumnya peneliti telah memaparkan bahwa materi kalkulus diferensial adalah materi prasyarat yang wajib dikuasai karena konsep penyelesaiannya digunakan pada materi kalkulus integral dan kalkulus peubah banyak). Hal ini senada dengan hasil penelitian Rezi Ariawan (2017) yang menyatakan bahwa subjek Field Independent mencoba menjawab dengan apa yang dipikirkannya, menganalisis dan memiliki penguasaan konsep yang lebih

baik. Sedangkan subjek Field Dependent mencoba menjawab, tetapi tidak memiliki kemampuan analisis dan penguasaan konsep yang baik.

\section{KESIMPULAN}

Berdasarkan hasil dan pembahasan, dapat disimpulkan bahwa temuan pada penelitian ini sesuai dengan konsep teori kepustakaan yang digunakan. Memang terdapat beberapa keunikan, namun hal tersebut masih dianggap wajar dalam suatu penelitian. Hasil yang ditunjukkan bahwa kesalahan yang dilakukan mahasiswa dalam menyelesaikan soal pada mata kuliah differensial terbagi atas tiga jenis kesalahan, yaitu kesalahan fakta, operasi dan prinsip serta kesalahan yang paling banyak dilakukan adalah kesalahan prinsip.

\section{UCAPAN TERIMAKASIH}

Peneliti mengucapkan terimakasih kepada Lembaga Penelitian dan Pengabdian Kepada Masyarakat UIN Suska Riau yang telah memberi bantuan dana terkait penelitian ini.

\section{DAFTAR PUSTAKA}

Abdurrahman, M. (2003). Pendidikan Bagi Anak Berkesulitan Belajar. Jakarta: Rineka Cipta

Costa, A. L dan Kallick, B. (2008). Learning and Leading with Habits of Mind 16 Esential Characteristic for Success. Virginia: Association for Supervision and Curriculum Development.

Hariyani, Mimi. (2014). Konsep Dasar Matematika. Pekanbaru: Benteng Media.

Marita, Rose Ash Shidiqi. (2014). Identifikasi Habits of Mind Siswa Praktikum dalam Diskusi serta Pengarubnya terbadap Penguasaan Konsep Sistem Organ. Tesis pada Sekolah Pascasarjana UPI Bandung: tidak diterbitkan.

O'Brien T.P., Butler, S.M., and Bernold, Le.E. (2001). Group Embedded Figures Test and Academic Achievement in Engineering Education. International Journal Engineering Ed. Vol 17, No 1, pp: 89-92.

Sukmadinata, Nana Syaodih. (2010). Metode Penelitian Pendidikan. Bandung: UPI Press.

Suryabrata, Sumadi. (2014). Metodologi Penelitian. Jakarta: PT. Raja Grafindo Persada.

Sternberg, R.I dan Elena, L.C. (1997). Are Cognitive Style Still in Style?. American Psychologist Association, Vol 52, No 7, pp: 700-712.

Ulya, Himmatul. (2015). Hubungan Gaya Kognitif Dengan Kemampuan Pemecahan Masalah Matematika Siswa. Jurnal Konseling GUSJIGANG Vol. 1 No.2 Tahun 2015, ISSN. 2480-1187. 
Witkin, H.A., Moore, C.A., Goodenough D.R., and Cox, P.W. (1977). Field Dependent and Field Independent Cognitive Styles and Their Educational Implications. Review of Educational Research Winter. Vol 47, No 1, pp: 1-64.

Woolfolk, Anita E. (1993). Educational Psychology 5 Edition. Singapore: Allyn and Bacon.

Zainal Abidin. (2012). Analisis Kesalahan Mahasiswa Prodi Pendidikan Matematika Fakultas Tarbiyah IAIN AR- Raniry dalam Mata Kuliah Trigonometri dan kalkulus 1. Jurnal Ilmiah Didaktika, 13 (1), 183-196. 